\title{
The Emergence of Winged Viviparous Female in Aphid
}

\author{
IV. The Effect of Light on the Development of Winged \\ Form in Rhopalosiphum prunifoliae
}

\author{
By Ichiro NodA \\ Biological Laboratory, Faculty of Education, Ehime University, Matsuyama, Ehime Pref.
}

\section{INTRODUCTION}

Light is recognized in general as one of the factors responsible for the development of winged form in aphid. Shull (1928, 1929 , 1932) made extensive studies on the problem in Macrosiphum solanifolii. He subjected the apterous females to various alternations of light and darkness, and examined the resulted destiny in the next generation. In my investigation, the results of which are now going to be presented, the young of the apple grain aphid, Rhopalosiphum prunifoliae, born parthenogenetically from apterous mothers are treated with various combinations of light and darkness, and the actual rates of wing formation were examined in the later stage of development, since, unlikely to the material used by Shull in which the future destiny of wing development is determined before birth of the young; the determination of future form takes place in their younger stages in this species.

I express my appreciation to Prof. K. Koidsumi of Gifu University for his valuable criticism and reading over the manuscript, and to Prof. I. Uchikawa of Ehime University for his encouragement that made this study possible to be carried on.

\section{MATERIAL AND METHOD}

The larvae derived from the unwinged viviparous females were fed in a glass tube $(2 \times 8 \mathrm{~cm})$ with leaves of Hordeum vulgare, cut into pieces of $10 \mathrm{~cm}^{2}$ at the rate of 5 individuals per piece under the constant temperature of $25^{\circ} \mathrm{C}$. The incubator, through the glass of which the light is able to pass in, was set in the place near the north window of the laboratory, so it was never illuminated by direct sunshine throughout the investigation. The intensity of diffused sunlight was usually more than 700 luxes even in the cloudy or rainy evenings without electric light. At night the incubator was illuminated at 580 luxes by two lamps of 60 watts from both sides. The artificial illumination was begun every evening before the natural light in the laboratory decreased less than 700 luxes and was discontinued after it increased to exceed 700 luxes.

\section{RESULT}

Experiment I. Upon undertaking to learn roughly whether the light intensity would affect the rate of wing development, one group of newly born larvae were exposed to daylight for 10 hours from $7 \mathrm{a} . \mathrm{m}$. to $5 \mathrm{p} . \mathrm{m}$., and another group born at 7 p.m. was treated with the light of electric lamps for the same duration from 7 p.m. to $5 \mathrm{a} . \mathrm{m}$. of the next day. Both groups were then subjected to darkness untill the critical period of wing determination passed away. In this case the intensity of daylight was $5,680 \pm 686$ luxes in average and that of the night lamps was 580 luxes. As shown in the following table there was no significant difference in the alate form appearance.

Experiment II. Similar observation was made in the larvae but fed for 30 hours in darkness from their birth (Table II).

Two intensities of light in this case produced no significant difference either. It is, how-

Received for publication, February 24, 1958. 
Table I. Light intensity and wing development of newborn larvae.

\begin{tabular}{c|c|c|c|c}
\hline $\begin{array}{c}\text { Light intensity } \\
\text { (luxes) }\end{array}$ & Total & Unwinged & \multicolumn{2}{|c}{ Winged } \\
\cline { 2 - 5 } $5,680 \pm 686$ & 117 & 110 & 7 & 6.0 \\
580 & 104 & 102 & 2 & 1.9 \\
\hline
\end{tabular}

Table II. Light intensity and wing development of larvae fed 30 hours in darkness.

\begin{tabular}{c|c|c|c|c}
\hline \hline $\begin{array}{c}\text { Light intensity } \\
\text { (luxes) }\end{array}$ & Total & Unwinged & \multicolumn{2}{|c}{ Winged } \\
\hline $\begin{array}{c}\text { Number } \\
4,390 \pm 524\end{array}$ & 52 & 43 & 9 & 17.3 \\
580 & 47 & 37 & 10 & 23.4 \\
\hline
\end{tabular}

ever, to be noted that there are differences of significance (within 2 and 1 per cent level respectively) between the corresponding lots of strong and weak lights in the present and preceeding experiments. From this it appears that the larvae are more sensitive to the action of light in the wing development in the stage nearer to the critical period of winged form determination than in the stage immediately after the birth. This point will become clearer by the following experiments.

Experiment III. A large number of the newly born larvae were divided into six groups, each consisting of about 110-140 individuals. The first group was exposed to natural and artificial lights during the whole development from the birth to the end of the fourth instar, the second for 40 hours from the birth, the third for 30 hours, the fourth for 20 hours, the fifth for 10 hours, and the sixth for 0 hour (not exposed) respectively. During the period unexposed to light all groups except the first were confined in complete darkness till the wing buds became visible. Table III gives the numbers of winged and unwinged forms produced. In this case also, no discernible difference was found in the rate of wing deveiopment.

Experiment IV. The young were treated by a method just reverse to the preceeding experiment; namely they were placed in complete darkness for $10,20,30$ and 40 hours respectively and then exposed to light until
Table III. Exposure to light for various duration from birth and wing development.

\begin{tabular}{l|c|c|c|c}
\hline \multicolumn{1}{c|}{$\begin{array}{c}\text { Hours of } \\
\text { exposure }\end{array}$} & Total & Unwinged & \multicolumn{2}{|c}{ Winged } \\
\cline { 3 - 5 } & & & Number & $\%$ \\
\hline Whole period** & 109 & 100 & 9 & 8.3 \\
40 hours & 108 & 102 & 6 & 5.6 \\
30 hours & 120 & 116 & 4 & 3.3 \\
20 hours & 134 & 126 & 8 & 6.0 \\
10 hours & 112 & 102 & 10 & 8.9 \\
0 hour* & 139 & 128 & 11 & 7.9 \\
\hline
\end{tabular}

the fourth instar. The result is seen in the following table.

Table IV. Confinement in darkness for: various duration from birth and wing development.

\begin{tabular}{l|r|r|r|r}
\hline \multicolumn{1}{c|}{$\begin{array}{c}\text { Hours in } \\
\text { darkness }\end{array}$} & Total & Unwinged & \multicolumn{2}{|c}{ Winged } \\
\cline { 3 - 5 } & & & Number & $\%$ \\
\hline Whole period* & 139 & 128 & 11 & 7.9 \\
40 hours & 91 & 82 & 9 & 9.9 \\
30 hours & 155 & 125 & 30 & 19.4 \\
20 hours & 84 & 58 & 26 & 30.9 \\
10 hours & 122 & 98 & 24 & 19.7 \\
0 hour** & 109 & 100 & 9 & 8.3 \\
\hline
\end{tabular}

The data marked with $*$ and $* *$ are common to those in Table III.

Significant differences of 5 per cent level exist in the percentage of wing develomepnt between the " 40 hours" and the " 30 hours", between the " 30 hours" and the " 20 hours" and between the " 10 hours" and the " 0 hour". The difference between the " 20 hours" and the "10 hours" also seems significant in the level nearly equal to 5 per cent $(d f=1$, $x^{2}=3.442$ ). However, difference can not be found between the "whole period" and the " 40 hours". The differences in the rate of wing development between the corresponding lots of the " 30 hours", " 20 hours" and " 10 hours" in the Tables III and IV are discernible respectively.

From these results, it is evident that the light exposure after treatment in darkness immediately after birth makes a marked contrast in the effect on the rate of wing development to that without previous sojourn in darkness, and that the effect of the former is different with the durations during which the young are in the darkness, the highest 
percentage being obtainable in the " 20 hours" lot. Small percentages such as 8-9 per cent seen in Tables III and IV always occured in every control lot, on account of unknown causes, where the larvae spent their whole life in darkness throughout the present experiment. If we subtract this unavoidable value of percentage from those presented in Table IV, we can obtain a normal curve ${ }^{1}$ (Fig. I)

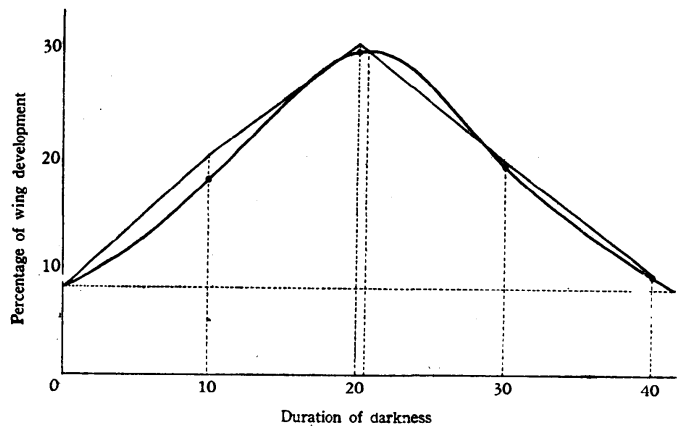

Fig. I. Normal curve which indicates the relation between the percenta $e$ value of wing development and the duration of exposure to darkness immediately after birth.

showing the relation between the theoretical number of alate forms and the duration of pretreatment in darkness.

Experiment V. Darkness and illumination were alternated every 20 hours in one group of newly born larvae and every hour in another group to know their influence upon wing development until the wing buds become visible with the following result (Table V).

Table V. Alternation of light and darkness and wing development.

\begin{tabular}{c|r|c|c|c}
\hline $\begin{array}{c}\text { Alternating } \\
\text { every }\end{array}$ & Total & Unwinged & \multicolumn{2}{|c}{ Winged } \\
\hline Number & $\%$ \\
\hline 1 hours & 95 & 70 & 25 & 26.3 \\
\hline
\end{tabular}

Since the critical period of determination of wing development lies between the 35 th and the 38.5 th hour after birth at $25^{\circ} \mathrm{C}$, the effect of light in the case of " 20 hours alternation" should be the same as that of " 20 hours in darkness" presented in Table
IV. This was the actual case. The former shows a significant difference not only to the "whole period in darkness" but also to the "whole period under light" with similar level of confidence between the latter and the so-called two "whole periods". The difference in the results between alternations of every 20 and 1 hour is significant at 5 per cent level, but that between " 1 hour alternation" and the two "whole periods" is not recognized. From these results it may be said that a continuous exposure to light followed by a continuous confinement in darkness in the younger stage previous to the critical period yields higher rate of winged form emergence than the periodical or intermittent light alternated with the darkness of short duration such as 1 hour.

Experiment VI. Newborn larvae were divided into two groups after normal feeding of 20 hours in darkness. Then they were starved either in light or in darkness for 10 hours respectively, and they were again given food till the wing buds became visible. In Table VI the result is presented.

Table VI. Light exposure under starvation and wing development.

\begin{tabular}{l|c|c|c|c}
\hline \multirow{2}{*}{ Lot } & Total & Unwinged & \multicolumn{2}{|c}{ Winged } \\
\cline { 3 - 5 } & & & Number & $\%$ \\
\hline In light & 118 & 67 & 51 & 43.2 \\
In darkness & 108 & 76 & 32 & 29.6 \\
\hline
\end{tabular}

The difference in wing development between "in light" and "in darkness" is of significance at the level of 5 per cent, so it is clear that light acting during starvation also has connection with the formation of alate form.

\section{DISCUSSION}

So far as the results of the present Experiments I and II are concerned, the intensity of light appears to have little to do with the rate of production of the winged form in this aphid. This agrees with the finding of Shull (1929) in Macrosiphum solanifolii. For instance, he demonstrated

\footnotetext{
${ }^{1}$ Degree of freedom is 4 and $x^{2}$ is 1.729 , so the null-hypothesis of normal distribution can not be rejected.
} 
that the light of various intensities ranging from 37 to 10,000 meter-candles, to which the unwinged females were exposed daily for 5 hours, does not yield any recognizable differences on the production of alate forms in the next generation. In my observations also, the weak light, when acting so long a time as more than 10 hours, showed almost the same effect $u$ pon the wing development as that of the strong lights (Tables I and II). That is, no significant differences were found even in the cases where the differences in the light intensity were so great as about $4,000 \sim 5,000$ luxes $(5,680$ or 4,390 to 580 luxes), much less in the cases of small differences; since the aphids, by their negative phototaxis, ta se refuge in the shady side of leaves which are varied in thickness and colouration, regardiess of light intensity, and even strong light can not act upon them by its real intensity.

Our observations showed that the winged form is never prociuced from the larvae which were treated with light during the early stage of development (Experiment III), but from those subjected to darkness in the younger stage and thereafter exposed to light (Experiment IV). This may mean that some physiological preparations which make the future transformation into pterous aphid possible are established in their bodies during the younger period when they are in darkness. In other words, it is likely that the action of light is not primary but secondary througn the action of internal physiological processes.

As seen in Tables III and IV, the differences in the rate of alate form emergence between the "whole period" in darkness and in light do not show any statistical differences. This seems to suggest that the effect of light is not derived from the changes in the nutritive properties of food plant, even if they take place, as was already pointed out by Shull (1929). This was more clearly demonstrated in Experiment VI.

It can be seen from the normal curve drawn in Fig. I that the highest percentage value of alate form is obtained theoretically, when the young are dealt with darkness for 20.5 hours immediately after birth and thereafter exposed to light to the time of wing bud appearance. Accordingly, the most susceptible time for wing development is believed to lie near the 20.5 th hour after birth. This agrees approximately with the result published in the previous paper (NODA '58).

It was indicated in Experiment $\mathrm{V}$ that continuous light (20 hours) seems more ef fective in the production of the pterous form than the intermittent one (alternated with darkness every one hour), because the percentage value are definitely higher in the former, notwithstanding the fact that the total duration of light exposure during the development prior to critical period are the same with both lots, if we regard it as 38 th hour after the birth. The intermittent light may not be so effective a mean for the production of wing as significant difference can be seen in comparison with the results in the "whole: period" in darkness and in light. This may be explainable on the basis that the secretion of some hormone like substance which is responsible for the wing development is disturbed by such a mode of exposure to light.

A hypothesis was proposed by Shull (1929) on the mechanism of action of light on the wing development. According to this hypothesis, substance A may be produced in the larval body during the exposure to light, which is to be converted into another substance B in the darkness, which changes again into $\mathrm{A}$ by light, and thus the wing develops when a definite amount of $B$ is present or it bears a certain ratio to that of A. Nevertheless in the present series of observation, there are not a few phenomena too difficult to be explained by such a hypothesis. To solve this problem, I believe that more detailed studies must be made.

\section{SUMMARY}

The effects of light and darkness on the future development of wing were examined experimentally in the larvae of apple grain aphid, Rhopalosiphum prunifoliae, at a con- 
stant temperature of $25^{\circ} \mathrm{C}$ with the following results.

1. The differenc in the rate of wing development does not occur in the range of intensities of light between about 4,000 5,000 and 580 luxes.

2. Far greater number of alate form are produced from larvae which were subjected to darkness in the early stage of development and thereafter exposed to light than from those treated by just the reverse way. The highest percentage value is obtained when the young are dealt with darkness for 20.5 hours since the birth.

3. Even when the total light exposures during the precritical period of determination of future wing development are the same, the alternation of light and darkness of every
20 hours is far more effective in comparison with that of every hour in which the rate of alate form effected is not different from that of the young treated with either light or darkness throughout the development.

4. The light action in the wing development does not depend upon the changes in the nutritional properties of the food plant, if they actually occur through the action of light.

\section{LITERATURE CITED}

NodA, I. (1958) Jap. Jour. Appl. Ent. Zool. 2: 53.

Shuld, A. F. (1928) Arch. Entwmech. 113: 210.

ShUll, A. F. (1929) Arch. Entwmech. 115: 825.

Shull, A. F. (1932) Amer. Nat. 66: 180.

アブラムンの有翅型胎生雌の出現について

IV. キビクビレアブラムシ Rhopalosiphum prunifotiae に打ける有翅型出現に対する光の影響

野 田 一 郎

愛媛大学教育学部

キビクビレアブラムン Rhopalosiphum prunifoliae 無翅型胎生雌から生じた幼虫に光を当て, その有翅型出 現に対する影響力を調べた。実験はすべて $25^{\circ} \mathrm{C}$ の定温 下で行い，食草としてはオオムギ Hordeum vulgare の 葉を与えた。光を照射する場合にはガラス張りの定温器 中に移し, 夜間は $60 \mathrm{~W}$ の電光で両側より照明した。実 験結果を要約すれば次のとおりである。

1） $4000 \sim 5000$ ルクスの光を当てても 580 ルクスの 光を当てても有翅型の出現率には有意の差が見られなか った。

2）生直後の幼虫を光に当てたのちに暗黒中に入れる と光の照射時間の長短にかかわらずほとんど有翅型には ならないが, 反対に最初暗黒中に入れ，しかるのちに光
を照射すると多数の有翅型が出現する。したがって幼虫 が暗黒中にある間に有翅型に変化しうるような素地がそ の体内に醇成され，乙の素地を生じた幼虫が光の刺激に よって有翅型になるのではないかと考えられる。その最 高出現率が見られるのは理論上では生直後の幼虫を20.5 時間暗黑中に入れたのちに光に当てた場合である。

3）生翅の臨界期前に扣ける光の照射時間は同じであ っても, 断続光 ( 1 時間でと)より連続光 (20時間) の 場合のはうが有翅型出現に対する影響力が大きい。

4）生翅に対する光の影響は直接的であって, 光が食 草の成分を変化させ，それによって影響を与えるという がでとき間接的なものではない。 